\title{
MENINGKATKAN KINERJA KEPALA MADRASAH DALAM MELAKSANAKAN SUPERVISI KELAS MELALUI SUPERVISI MANAJERIAL PENGAWAS PADA MADRASAH BINAAN MIS KECAMATAN PRINGAPUS KABUPATEN SEMARANG
}

\author{
ADI HERMAWAN \\ Pengawas Madrasah Kementerian Agama Kabupaten Semarang \\ e-mail: adihermawan68@gmail.com
}

\begin{abstract}
ABSTRAK
Penelitian kualitatif yang bertujuan mendeskripsikan sasaran supervisi manajerial sebagai langkah pengelolaan administrasi madrasah yang berfungsi sebagai pendukung terlaksananya pembelajaran, dan bertujuan agar terciptanya pendidikan yang relevan. Tujuan dari penelitian tindakan ini adalah untuk mengetahui sejauh mana pengaruh supervisi manajerial dalam meningkatkan kinerja kepala madrasah di madrasah binaan MIS Kecamatan Pringapus Kabupaten Semarang tahun pelajaran 2021-2022. Dalam penelitian tindakan ini dilakukan dalam 2 siklus, dari hasil tindakan yang dilakukan terbukti dapat meningkatkan kinerja kepala madrasah dengan mencapai standar ideal. Dari 70,00\% pada Siklus 1, dapat meningkat menjadi 91,25\% pada siklus II, Hasil penelitian tindakan ini menunjukkan bahwa pembinaan pengawas melalui supervisi manajerial adalah efektif dapat meningkatkan kinerja kepala madrasah binaan di MIS Kecamatan Pringapus Kabupaten Semarang.
\end{abstract}

Kata Kunci: Peningkatan Kinerja Kepala Madrasah, Supervisi Manajerial.

\section{ABSTRACT}

Qualitative research that aims to describe the objectives of managerial supervision as a step in managing school administration that functions as a supporter of the implementation of learning, and aims to create relevant education. The purpose of this action research is to determine the extent of the influence of managerial supervision in improving the performance of principals in the target schools at MIS Kecamatan Pringapus Kabupaten Semarang for the academic year 2021-2022. In this action research was carried out in 2 cycles, from the results of the actions taken it was proven to be able to improve the performance of the principal by achieving the ideal standard. From 70,00\% in Cycle I, it can increase to $91,25 \%$ in Cycle II. The results of this action research show that supervising supervisors through managerial supervision is effective in improving the performance of principals in the target schools at MIS Kecamatan Pringapus Kabupaten Semarang.

Keywords: Principal Performance Improvement, Managerial Supervision.

\section{PENDAHULUAN}

Menurut N. McGinn. T. Welsh (1999:14) mengatakan bahwa meningkatnya kualitas pendidikan merupakan akibat langsung dari kemampuan untuk melakukan standarisasi, ketepatan dan isi pendidikan yang dibuat melalui perencanaan pemerintah mengenai apa sasaran yang akan dicapai dalam sekolah, apa yang bisa diajarkan, siapa yang bisa diajar, siapa yang bisa mengajar, di mana pengajaran akan dilangsungkan, dan bagaimana sekolah akan dibiayai.

Dalam perspektif globalisasi otonomi daerah dan desentralisasi pendidikan serta untuk mensukseskan Manajemen Berbasis Sekolah (MBS), tugas fungsi dan wewenang kepala sekolah merupakan figur sentral yang harus menjadi teladan bagi para tenaga kependidikan lain di sekolah. Oleh karena itu, untuk menunjang keberhasilan dalam perubahan-perubahan yang dilakukan dan diharapkan, perlu dipersiapkan kepala sekolah yang profesional, yang mau dan mampu melakukan perencanaan, pelaksanaan serta evaluasi terhadap berbagai kebijakan dan perubahan yang dilakukan. Kepala Sekolah yang diberi kewenangan mengatur sekolah agar sesuai dengan situasi dan kondisi masyarakat dan dalam pengambilan keputusan yang harus melibatkan Stakeholder sekolah masih tampaknya belum baik dan merata. Sehingga dapat dibayangkan kepala sekolah yang belum banyak 
berperan sebagai pelaksana. Kemudian karena tugas yang sangat besar, secara mendadak menangani tugas dan fungsi mulai dari perencanaan, pelaksanaan sampai pada pengendalian diperlukan peningkatan kemampuan mereka, sehingga dapat menangani tugas baru yang jauh lebih luas dengan sebelumnya (Depdiknas, 2003:5).

Di samping perubahan paradigma berpikir yang cukup mendasar, disentralisasi baik ditingkat kabupaten/kota maupun tingkat sekolah dan masyarakat sebagai konsekuensi pelaksanaan Manajemen Peningkatan Mutu Berbasis Sekolah (MPMBS), maka diperlukan sumber daya yang memadai di antaranya sumber daya manusia.

Untuk menjadi kepala sekolah yang profesional, banyak hal yang harus dipahami, banyak masalah yang harus dipecahkan, dan banyak strategi yang harus dikuasai. Kurang adil jika pengangkatan kepala sekolah hanya didasarkan pada pengalaman menjadi guru yang diukur dari segi waktu (lama menjadi guru). Untuk menjadi kepala sekolah profesional perlu dimulai dari pengangkatan yang profesional pula (Mulyasa, 2003:1)

Untuk mengatasi masalah di atas pemerintah dalam hal ini Kemendikbud mengeluarkan kebijakan melalui program-program peningkatan mutu pendidikan. Program peningkatan mutu pendidikan ini dimaksudkan untuk meningkatkan kemampuan kepala sekolah dan guru dalam melaksanakan tugas dan fungsinya di sekolah. Sehingga para guru dan kepala sekolah lebih siap mental untuk melaksanakan tugas di sekolah, berwibawa dan dapat melaksanakan konsep cara belajar siswa aktif (Depdiknas, 2003:11).

Selanjutnya untuk menjaga keberlanjutan manajemen kependidikan yang bermutu, maka diperlukan program pemberdayaan personil dan lembaga melalui pelatihan yang dilaksanakan oleh lembaga profesional. Program pemberdayaan ini perlu diikuti dengan monitoring dan evaluasi secara bertahap dan intensif agar kinerja kepala sekolah dapat bertahan sesuai dengan standar mutu pendidikan yang ditetapkan (Depdiknas, 2003:14).

Pelaksanaan pengawasan pendidikan merupakan realisasi dari fungsi manajemen pendidikan. Pengawasan dapat diarahkan pada kegiatan akademik dan administrative (manajerial). Pelaksanaan pengawasan kegiatan akademik yaitu pelaksanaan pengawasan terhadap kegiatan proses pembelajaran yang meliputi pengawasan kegiatan guru pandidikan agama Islam dalam merencanakan, melaksanakan dan mengevaluasi pembelajaran agama Islam (Fazis, 2009:18).

Wahjosumidjo (2002 : 82) mengatakan bahwa kepala sekolah dalam menggerakkan kehidupan sekolah mencapai tujuan ada 2 (dua) hal yang perlu diperhatikan yaitu :

1. Kepala sekolah berperan sebagai kekuatan sentral yang menjadi kekuatan penggerak kehidupan sekolah.

2. Kepala sekolah harus memahami tugas dan fungsi mereka demi keberhasilan sekolah serta memiliki kepedulian terhadap staf dan siswa.

Untuk meningkatkan kemampuan kepala madrasah dalam menjalankan peran dan fungsinya secara efektif terutama kepala madrasah yang baru menjabat, maka pelatihan peningkatan mutu pendidikan ini sangat diperlukan sehingga keefektifan dan tujuan pembelajaran di madrasah dapat tercapai.

Sehubungan dengan hal di atas di Kecamatan Pringapus kabupaten Semarang sering diadakan pelatihan-pelatihan untuk meningkatkan kompetensi kepala madrasah (pelatihan peningkatan kinerja kepala madrasah) baik sesudah maupun sebelum mereka menjabat kepala madrasah, tetapi masih ada juga yang belum sempat mengikuti pelatihan dengan alasan teknis. baik dilaksanakan Kementerian Agama Kabupaten Semarang dengan Diklat di Wilayah Kerja maupun oleh Kementerian Agama Provinsi Jawa Tengah melalui Lembaga Balai Diklat Keagamaan Semarang, pelatihan kepala madrasah adalah pelatihan dalam upaya peningkatan kinerja kepala madrasah.

Kepada kepala madrasah yang belum mengikuti pelatihan maupun yang sudah mengikuti pelatihan kepala madrasah sangat diperlukan untuk membimbing dan membina para kepala madrasah, agar dapat meningkatkan kinerjanya secara efektif melalui supervisi manajerial.

Setelah mengikuti pelatihan peningkatan kinerja kepala madrasah, maupun yang belum mengikuti pelatihan dengan mendapat bimbingan dan pembinaan dari pengawas madrasah 
diharapkan akan dapat meningkatkan kinerjanya sebagai kepala madrasah. Oleh karena itu peneliti mencoba mengadakan penelitian tindakan kepengawasan (PTKp) tentang sejauh mana peran bimbingan pengawas sekolah dalam: "Meningkatan Kinerja Kepala Madrasah Melaksanakan Supervisi Kelas Melalui Supervisi Manejerial Pengawas di Madrasah Binaan MIS Kecamatan Pringapus Kabupaten Semarang"

\section{METODE PENELITIAN}

Penelitian ini merupakan penelitian tindakan kepengawasan, yaitu pencermatan terhadap kegiatan kepengawasan berupa sebuah tindakan, yang sengaja dimunculkan dan terjadi dalam satu madrasah binaan. Dalam pelaksanaannya peneliti dapat melakukan penelitian tindakan kepengawasan secara mandiri maupun kolaboratif partisifatif, akan tetapi tidak boleh menghambat kegiatan utama Kepala Sekolah dalam melaksanakan tugas dan tanggung jawabnya (Arikunto, 2008).

Penelitian ini dilakukan secara kolaboratif partisipatif, dimana Peneliti (Pengawas Madrasah) secara bersama-sama dengan Subyek Penelitian (Kepala Madrasah) melaksanakan penelitian ini langkah demi langkah. Dalam penelitian tindakan kepengawasan ini teknik supervisi Manajerial yang akan dilaksanakan adalah Teknik supervisi individual. Sedangkan teknik supervisi yang akan diteliti atau dilaksanakan dalam Penelitian Tindakan kepengawasan ini adalah a) teknik kunjungan kelas, b) observasi kelas, dan c) pertemuan individual. Subyek dalam penelitian ini adalah Kepala Madrasah yang berada di MIS Kecamatan Pringapus Kabupaten Semarang yang menjadi Binaan Pengawas (Peneliti) tahun pelajaran 2020-2021.

\section{HASIL DAN PEMBAHASAN}

\section{Hasil}

\section{Siklus I}

\section{a) Tahap Perencanaan}

Pada tahap ini peneliti mempersiapkan perangkat pembinaan yang terdiri dari rencana kepengawasan, soal tes formatif 1 dan alat-alat pembinaan lain yang mendukung. Selain itu juga dipersiapkan lembar observasi peningkatan kinerja kepala sekolah dengan pemberian balikan.

\section{b) Tahap Kegiatan dan Pelaksanaan}

Pengamatan (observasi) dilaksanakan bersamaan dengan pelaksanaan pembinaan di sekolah. Pada akhir proses pembinaan kepala sekolah diberi tes formatif I dengan tujuan untuk mengetahui tingkat keberhasilan kepala sekolah dalam meningkatkan kinerjanya sesuai dengan yang telah dilakukan. Adapun data hasil penelitian pada siklus I. Adalah seperti pada tabel berikut:

Tabel 1. Tabel Distribusi Nilai tes Pada Siklus I

\begin{tabular}{|c|l|c|c|c|}
\hline \multirow{2}{*}{ No } & \multirow{2}{*}{ Nama Sekolah } & \multirow{2}{*}{ Skor } & \multicolumn{2}{|c|}{ Keterangan } \\
\cline { 4 - 5 } & & & Tuntas & $\begin{array}{c}\text { Tidak } \\
\text { Tuntas }\end{array}$ \\
\hline 1 & MI Al Mustajab & 80 & $\sqrt{ }$ & \\
\hline 2 & MI Wonoyoso & 75 & $\sqrt{ }$ & \\
\hline 3 & MI Al Huda & 60 & & $\sqrt{ }$ \\
\hline 4 & MI Hidataul Mubtadiin & 65 & & $\sqrt{ }$ \\
\hline Jumlah Total & $\mathbf{2 8 0}$ & - & - \\
\hline Skor Maksimum Individu & $\mathbf{1 0 0}$ & - & - \\
\hline $\begin{array}{l}\text { Skor Maksimum Kelompok } \\
\text { Kepala Sekolah ( SMK ) }\end{array}$ & $\mathbf{4 0 0}$ & - & - \\
\hline
\end{tabular}


Keterangan :

Jumlah Kepala Madrasah yang tuntas : 2 Orang

Jumlah Kepala Madrasah yang belum tuntas : 2 Orang

Kelompok Kepala Madrasah

: belum tuntas.

Dari tabel di atas dapat dijelaskan bahwa dengan pembinaan yang dilakukan oleh pengawas melalui supervisi manajerial diperoleh nilai rata-rata peningkatan kinerja kepala madrasah adalah $70,00 \%$ atau ada 2 kepala sekolah dari 4 orang sudah tuntas. Hasil tersebut menunjukkan bahwa pada siklus pertama secara kelompok kepala madrasah belum meningkat kinerjanya, karena yang memperoleh nilai $\geq 75$ hanya sebesar 50,00\% lebih kecil dari persentase ketuntasan yang dikehendaki yaitu sebesar $85 \%$. Hal ini disebabkan karena banyak kepala madrasah yang baru diangkat/dilantik menjadi kepala sekolah sehingga mereka merasa baru dengan tugas tersebut.

\section{c) Refleksi}

Dalam pelaksanaan kegiatan pembinaan diperoleh informasi dari hasil pengamatan sebagai berikut:

(1) Pengawas masih kurang teliti dalam melakukan pembinaan di sekolah

(2) Pengawas masih kurang baik dalam pemanfaat waktu

(3) Pengawas Sekolah masih kurang konsentrasi dalam melakukan pembinaan, karena ada trugas lain yang harus dikerjakan.

\section{Siklus II}

\section{a) Tahap perencanaan}

Pada tahap ini peneliti mempersiapkan perangkat pembinaan yang terdiri dari rencana kepengawasan 2, soal tes formatif II dan alat-alat kepengawasan lain yang mendukung.

\section{b) Tahap kegiatan dan pelaksanaan}

Dalam hal ini peneliti bertindak sebagai pengawas. Adapun proses pembinaan mengacu pada rencana pembinaan dengan memperhatikan revisi pada siklus I, sehingga kesalahan atau kekurangan pada siklus I tidak terulang lagi pada siklus II. Penelitian tindakan kepengawasan ini dilaksanakan sesuai dengan prosedur rencana pembinaan dan skenario kepengawasan serta surat tugas yang diberikan oleh Kepala Kantor Kementerian Agama Kabupaten Semarang. Pada akhir proses pembinaan kepala madrasah diberi tes formatif II dengan tujuan untuk mengetahui tingkat keberhasilan kepala madrasah dalam meningkatkan kinerjanya. Instrumen yang digunakan adalah tes formatif, Adapun data hasil penelitian pada siklus II adalah sebagai berikut:

Tabel 2. Tabel Distribusi Nilai tes Pada Siklus II

\begin{tabular}{|c|c|c|c|c|}
\hline \multirow{2}{*}{ No } & Nama & \multirow{2}{*}{ Skor } & \multicolumn{2}{|c|}{ Keterangan } \\
\cline { 4 - 5 } & & & Tuntas & $\begin{array}{c}\text { Tidak } \\
\text { Tuntas }\end{array}$ \\
\hline 1 & MI Al Mustajab & 80 & $\sqrt{ }$ & \\
\hline 2 & MI Wonoyoso & 75 & $\sqrt{ }$ & \\
\hline 3 & MI Al Huda & 60 & $\sqrt{ }$ & \\
\hline 4 & MI Hidataul Mubtadiin & 65 & $\sqrt{ }$ & \\
\hline Jumlah Total & $\mathbf{3 6 5}$ & - & - \\
\hline \multicolumn{2}{|l|}{ Skor Maksimum Individu } & $\mathbf{1 0 0}$ & - & - \\
\hline $\begin{array}{l}\text { Skormaksimum Kelompok } \\
\text { Kepala Sekolah }\end{array}$ & $\mathbf{4 0 0}$ & - & - \\
\hline
\end{tabular}


Keterangan :

Jumlah Kepala Sekolah yang tuntas : 4 Orang

Jumlah Kepala yang belum tuntas : - Orang

Kelompok Kepala Sekolah : : tuntas.

Dari tabel di atas diperoleh nilai rata-rata peningkatan kinerja kepala sekolah adalah $91,25 \%$, dari 4 orang kepala madrasah dinyatakan sudah tuntas dalam meningkatkan kinerjanya. Hasil ini menunjukkan bahwa pada siklus II ini peningkatan kinerja kepala madrasah telah mengalami peningkatan lebih baik dari siklus I. Adanya peningkatan kinerja kepala madrasah ini karena setelah pengawas telah menginformasikan bahwa setiap akhir pembinaan akan diadakan penilaian sehingga pada pertemuan berikutnya kepala madrasah lebih termotivasi untuk meningkatkan kinerjanya. Selain itu kepala madrasah juga sudah mulai mengerti apa yang dimaksudkan dan diinginkan oleh pengawas dalam melakukan pembinaan supervisi manajerial ke sekolah.

c) Refleksi

Dalam pelaksanaan pembinaan diperoleh informasi dari hasil pengamatan sebagai berikut:

1) Memotivasi kepala madrasah

2) Membimbing kepala madrasah dalam menyusun rencana kerja madrasah merumuskan kesimpulan/menemukan konsep

3) Pengelolaan waktu

\section{Analisis Hasil Kegiatan}

Setelah dilakukan tindakan pada siklus 1, siklus 2 menunjukkan terdapat hasil yang cukup signifikan dalam kegiatan peningkatan supervisi manajerial yang dilakukan pengawas sekolah kepada kepala madrasah binaan di wilayah binaan Kecamatan Pringapus Kabupaten Semarang. Adapun hasil tidakan kegaiatan pelaksanaan anatara silus 1 dan siklus 2 ini dapat dijabarkan pada tabel berikut dibawah ini :

Tabel 3. Analisis Hasil Tes Tentang Pembinaan Pengawas Terhadap Peningkatan Kinerja Kepala Sekolah Melalui Supervisi Manajerial

\begin{tabular}{|c|c|c|c|}
\hline No & Nama & Skor sebelum & $\begin{array}{c}\text { Skor } \\
\text { setelah } \\
\text { Tindakan } \\
\text { Tindakan 1 } \\
\text { Siklus 1 }\end{array}$ \\
\hline 1 & MI Al Mustajab & 80 & 95 \\
\hline 2 & MI Wonoyoso & 75 & 9 \\
\hline 3 & MI Al Huda & 60 & 90 \\
\hline 4 & $\begin{array}{c}\text { MI Hidataul } \\
\text { Mubtadiin }\end{array}$ & 65 & 90 \\
\hline \multicolumn{2}{|c|}{ Jumlah Total } & $\mathbf{2 8 0}$ & $\mathbf{3 6 5}$ \\
\hline \multicolumn{2}{|l|}{ Skor Maksimum Individu } & $\mathbf{1 0 0}$ & $\mathbf{1 0 0}$ \\
\hline \multicolumn{2}{|l}{ Maksimum Kelas } & $\mathbf{4 0 0}$ & $\mathbf{4 0 0}$ \\
\hline
\end{tabular}

\section{Analisis Data Deskriptif Kuantitatif}

1. Pencapaian Peningkatan Kinerja Kepala Sekolah sebelum diberi tindakan

$$
=\frac{280}{400} \times 100 \%=70,00 \%
$$


2. Pencapaian peningkatan kinerja kepala madrasah setelah diberi tindakan melalui supervisi manajerial oleh pengawas

$=\frac{365}{400} \times 100 \%=91,25 \%$

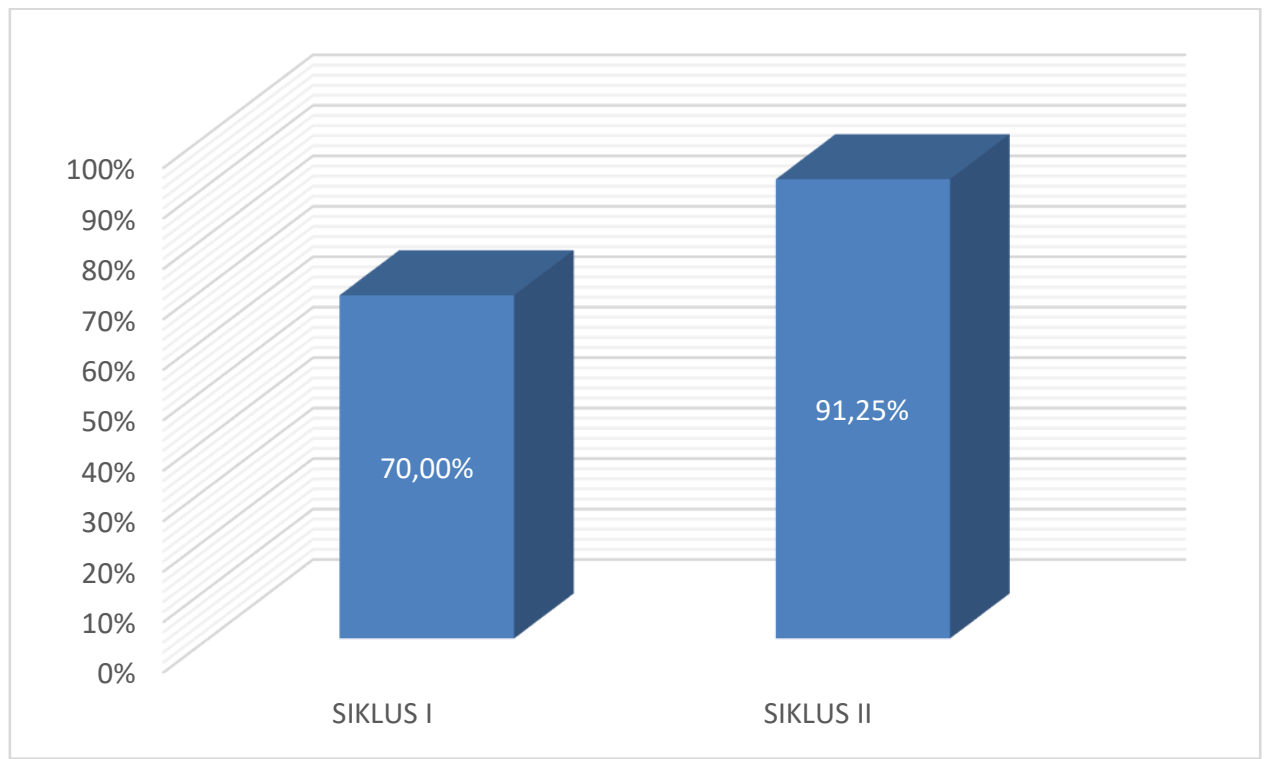

Gambar 1. Perbadingan Siklus I dan Siklus II

Dari hasil analisis tersebut dapat disimpulkan bahwa

A. Terjadi peningkatan kinerja setelah diberi pembinaan melalui supervisi manajerial yaitu peningkatan kinerja 70,00\% menjadi $91,25 \%$ ada kenaikan sebesar $=21,25 \%$

B. Dari sebelum pembinaan (siklus 1) dan setelah pembinaan oleh pengawas sampai dengan (siklus 2) $70,00 \%$ menjadi $91,25 \%$. Rata - rata kinerja kepala madrasah sebelum diberi pembinaan $70,00 \%$ naik $21,25 \%$ menjadi $91,25 \%$

\section{Pembahasan}

1. Ketuntasan Hasil Pembinaan Kinerja Kepala Madrasah

Melalui hasil penelitian ini menunjukkan bahwa pembinaan melalui supervisi manajerial memiliki dampak positif dalam meningkatkan kinerja kepala madrasah, hal ini dapat dilihat dari semakin mantapnya pemahaman kepala madrasah terhadap pembinaan yang disampaikan pengawas ( Kinerja kepala sekolah meningkat dari siklus I, dan II ) yaitu masingmasing 70,00\% ; 91,25\% Pada siklus II kinerja kepala madrasah secara kelompok dikatakan tuntas.

2. Kemampuan Pengawas dalam meningkatkan kinerja kepala sekolah

Berdasarkan analisis data, diperoleh aktivitas kepala madrasah dalam meningkatkan kinerjanya dalam setiap siklus mengalami peningkatan. Hal ini berdampak positif terhadap kinerja kepala madrasah yaitu dapat ditunjukkan dengan meningkatnya nilai rata-rata kepala madrasah pada setiap siklus yang terus mengalami peningkatan.

3. Aktivitas Pengawas dan Kepala Madrasah dalam Pembinaan melalui Supervisi Manajerial

Berdasarkan analisis data, diperoleh aktivitas pengawas dan kepala madrasah yang paling dominan dalam kegiatan supervisi manajerial adalah bekerja dengan menggunakan alat/media, mendengarkan/memperhatikan penjelasan pengawas, dan diskusi antar antar kepala madrasah dan pengawas. Jadi dapat dikatakan bahwa aktivitas kepala madrasah dapat dikategorikan aktif.

Sedangkan untuk aktivitas pengawas selama pembinaan telah melaksanakan langkah-langkah metode pembinaan melalui supervisi manajerial dengan baik. Hal ini terlihat dari aktivitas kepala madrasah yang muncul di antaranya aktivitas membuat dan merencanakan program 
madrasah,melaksanakan, memberi umpan balik/evaluasi/tanya jawab di mana prosentase untuk aktivitas di atas cukup besar.

Berdasarkan hasil penelitian di atas, peningkatan kinerja kepala madrasah melalui pembinaan supervisi manajerial hasilnya sangat baik. Hal itu tampak pada pertemuan pertama dari 4 orang kepala madrasah yang ada pada saat penelitian ini dilakukan nilai rata rata mencapai ; 65,25\% meningkat menjadi 91,25\% .

Dari analisis data di atas bahwa pembinaan kinerja pengawas melalui supervisi manajerial efektif diterapkan dalam upaya meningkatkan kinerja kepala madrasah, yang berarti proses pembinaan pengawas lebih berhasil dan dapat meningkatkan kinerja kepala madrasah khususnya kepala madrasah di Kecamatan Pringapus Kabupaten Semarang, oleh karena itu diharapkan kepada para pengawas dapat melaksanakan pembinaan melalui supervisi manajerial secara berkelanjutan.

Hal ini sesuai dengan penelitian dari Auliya, dkk (2018) yang berjudul Pelaksanaan Supervisi Manajerial Dalam Rangka Implementasi Manajemen Berbasis Sekolah. Dalam penelitian tersebut mengatakan bahwa peran pengawas dalam implementasi Manajemen Berbasis Sekolah penting adanya, karena setiap rekomendasi dari sebuah permasalahan yang dihadapi sekolah menjadikan sekolah memiliki inovasi untuk meningkatkan mutunya. Pengawas umumnya membina dan mendampingi ketika sekolah memiliki kendala di bidang tertentu, maka dari itu peran pengawas sangatlah dibutuhkan untuk kepentingan mutu sekolah.

\section{KESIMPULAN}

Berdasarkan analisis hasil penelitian dan diskusi dapat disimpulkan sebagai berikut :

Pembinaan Pengawas dalam upaya meningkatkan kinerja kepala sekolah melalui supervisi manajerial menunjukan peningkatan pada tiap-tiap putaran (Siklus). Aktivitas dalam kegiatan pembinaan menunjukan bahwa seluruh kepala madrasah dapat meningkatkan kinerjanya dengan baik dalam setiap aspek. Peningkatan kinerja kepala madrasah di MIS Kecamatan Pringapus Kabupaten Semarang oleh pengawas melalui supervisi manajerial ini menunjukan peningkatan pada tiap-tiap putarannya. Aktivitas kepala madrasah menunjukan bahwa kegiatan pembinaan melalui supervisi manajerial bermanfaat dan dapat membantu kepala madrasah untuk lebih muda memahami konsep peran dan fungsi kepala madrasah sehingga kinerja kepala madrasah dapat meningkat.

\section{DAFTAR PUSTAKA}

Arikunto, Suharsimi. (2008). Penelitian Tindakan Kelas. Jakarta: Bumi Aksara

Arikunto, Suharsimi. (2012). Dasar-Dasar Evaluasi Pendidikan. Jakarta: PT. Bumi Aksara

Auliya, Dhiyana Nur Sari., Bafadal, Ibrahim., Budi, Bambang Wiyono. (2018). Pelaksanaan Supervisi Manajerial Dalam Rangkaimplementasi Manajemen Berbasis Sekolah. JAMP: Jurnal Adminitrasi dan Manajemen Pendidikan, Volume 1 Nomor 2 : 213-221

Depdiknas. (2003). Kebijakan Direktorat Pendidikan Lanjutan Pertama. Jakarta : Direktorat Dikdasmen.

Fazis, Muhammad. (2009). Konstribusi Motivasi Berprestasi terhadap Kinerja Pengawas Pendidikan Agama Islam. Stutdia Akademika, Vol. 7 No. 1,

Mulyasa E. (2002). Manajemen Berbasis Sekolah. Konsep, Stragtegi, dan Implementasi. Bandung : PT. Remaja Rosdakarya.

Wahjosumidjo. (2002). Kepemimpinan Kepala Sekolah. Tinjauan Teoritik dan Permasalahannya. Jakarta : PT. Raja Grafindo Persada.

Welsh, McGinn. (1999). Decentralization of Education Why, When, What, and How? United Nations Educational Scientifiq and Cultural Organization. 7 Place Fortenoy, F 75352 Paris of SP 